\title{
BACK TO THE ROOTS? CRITICAL REFLECTIONS ON THE 'ROOT' IN FINNO-UGRIC LINGUISTICS
}

\author{
Johanna Laakso \\ University of Vienna
}

\begin{abstract}
In Finno-Ugric linguistics, words are usually analyzed in terms of stems and affixes instead of abstract monosyllabic 'roots' in the Indo-European sense. However, there have been attempts to introduce the concept of 'root' alongside the historically disyllabic stems, in order to account for less regular connections between words and the non-canonic word formation mechanisms of the expressive vocabulary. Here, a few such attempts are critically analyzed in their historical and ideological contexts.
\end{abstract}

Keywords: Finno-Ugric, Hungarian, Finnish, word structure, etymology, root, history of linguistics, expressive words

DOI: https://doi.org/10.12697/jeful.2017.8.1.08

\section{The roots of the 'root'}

The root as a linguistic term originates in Semitic linguistics, but in Europe, its best known uses are connected to Indo-European studies. The rise of this metaphor in historical-comparative linguistics was part of the general idea of organicism, life and growth which in Romantic science had a "semi-mystical value" (Morpurgo Davies 1998: 73). In Indo-European studies, the root gradually acquired a clearly defined meaning: roots are monosyllabic elements at the core of each lexeme, the core vowel of the root is subject to alternations (Ablaut), and affixes and other extensions can be attached to the root (see e.g. Fortson 2004: 70-76).

From an historical point of view, the Indo-European roots (such as *sed- 'sit' present in, for example, English sit, nest, and soot) are tools of reconstruction which are not necessarily real for today's speakers. The term "root" thus forms a powerful multiple metaphor: roots are invisible, underground, and they metaphorically represent both the historic origins of a language and an existing mechanism which maintains its life and growth. 
In Finno-Ugric studies, instead of 'root', normally the term 'stem' (Estonian tüvi Hungarian tö, Finnish vartalo) is used. The FinnoUgric stem is not abstract but recognizable and often psychologically real even for today's speakers, with segmentable inflectional or derivational suffixes (more marginally, prefixes) and often able to appear as a free lexical morph. Moreover, Finno-Ugric lexical (content-word) stems were originally disyllabic, with the exception of monosyllabic deictic and grammatical words. Even if some Finno-Ugric languages, such as Estonian and Livonian, have lost many important suffixes while developing extensive morphophonological stem alternations, and even if the underived stems in many Finno-Ugric languages have turned monosyllabic, the concept of 'stem', however variable, still belongs to the basic tools of grammatical analysis.

At times, however, the term 'root' (Estonian (sõna)juur, Finnish juuri, Hungarian gyök) is also used in connection with Finno-Ugric languages. In the most cases, this is due to ignorance, and also to the attractiveness and metaphoric power of the 'root' (and its established position in Indo-European linguistics). However, there have also been attempts to introduce the root as a linguistic term distinct from the word stem. These will be surveyed in this article.

\section{The 'root' in 19th-century Finno-Ugric studies}

\subsection{Hungary: The Czuczor-Fogarasi dictionary and other works on 'roots'}

At the turn of the 19th century, one of the central goals of the language reform activists in Hungary was a comprehensive, up-to-date dictionary of Hungarian. Among the works preparing the ground for this, the dictionary by Kresznerics (1831-1832) introduced the concept of 'root' into Hungarian language studies. 'Roots' (gyök, a neologism clipped from gyökér 'root in the botanical sense') were soon adopted in lexical analysis and etymology, and already in 1834, the Hungarian Academy of Sciences announced an award for a list of "pure roots" and their meanings in the Hungarian language. (Németh 2007: 55-59, 175.)

In 1844, the Academy assigned the writing of the new Hungarian dictionary to the Benedictine monk Gergely Czuczor, with the lawyer and polyhistor János Fogarasi as the assistant editor (vizsgáló). The first volumes appeared in 1862, and the sixth and last volume (after 
Czuczor's death in 1866, finalized by Fogarasi) in 1874. In all, the dictionary comprises 110,784 word entries. (Németh 2007: 59-65.)

The Czuczor-Fogarasi dictionary (henceforth: $\mathrm{CzF}$ ) begins with a long introduction to its method. Words will be broken down to monosyllabic roots, which in turn can take different word-forming suffixes. Roots include "living roots" (free morphs, for example: rossz 'bad'), "dead" or "abstract roots" (holt/elvont gyök) or root elements (gyökelem), i.e. bound morphs such as roh- in rohad 'rot' [v.], and "sprouts" (csira), such as the element ro- in rohad, rossz 'bad', rozsda 'rust', etc. Moreover, the roots form families based on similarities in form and meaning. The root kar in karika 'ring, hoop' belongs together with ker in kerek 'round', kor in korong 'disk', kör in körül 'around' and kur in kurittol 'wind (around), loaf about' etc., and these, in turn, are related to gör in görbe 'curved', gur in gurul 'roll' [v.], gyür in gyürü 'ring (on finger)', hor in horog 'hook', kal in kaland 'adventure' etc., to quote just a few examples. (CzF I: 15-17.)

The introduction also presents a long list of roots (op. cit. 66-118), many of which are homonymous (for instance: tal in talp 'footsole', tal $(\sim$ tol $)$ in talicska 'wheelbarrow' and tal in talál 'find', talán 'perhaps' etc. are three different roots). In the dictionary part proper, some abstract roots have separate entries (for instance: $a b r$, the abstract root present in abrosz 'tablecloth', is related to bor in borit 'cover' [v.] etc.).

Despite its merits as an unprecedented collection of valuable lexical material, $\mathrm{CzF}$ was soon subjected to heavy criticism. Its approach to etymology was incompatible with the professionalizing historical linguistics. $\mathrm{CzF}$ failed to recognize obvious loanwords (for example, there is no reason to postulate a root $a b r$ - for abrosz 'tablecloth', a loanword with an impeccable Slavic etymology ${ }^{1}$ ) or deal with historical processes in general. Czuczor and Fogarasi had not even attempted to describe language change but simply performed ad hoc comparisons between word roots and families, wherever intuitive similarity was given. For instance: Latin batuo 'I beat', batulus 'stick', French battre, baton can be compared with Hungarian bot 'stick', botoz 'beat with a stick', botlik 'stumble' or even botránkozik 'be scandalized' (CzF I: 21-22). Moreover, in their foreword (CzF I: 31) Czuczor and Fogarasi explicitly refuse to take a stand on the issue of the "Altaic" (= "UralAltaic") relatedness of Hungarian, stating that systematic comparison

1 The Slavic obrusb is formed from the prefix o- and the stem brus- 'wipe', see e.g. Vasmer 1955 II: 245. 
of data is still needed before "languages can be organized into internal and external systems [of relatedness]". However, mainstream linguists worldwide, already since Sajnovics's Demonstratio in 1770, had little doubts about the relatedness between Hungarian and the Finnic-Saami languages (Stipa 1990: 192, 212).

As CzF's views on etymology and historical linguistics became recognized as outdated, the merits of the dictionary were forgotten as well. During most of the 20th century, CzF was merely mentioned in passing or totally ignored. Recently, however, in connection with the rise of nationalistically motivated pseudolinguistic theories (see e.g. Marácz 2009: 26-27, Laakso 2010), $\mathrm{CzF}$ as a source for alternative "genuine Hungarian" etymologies has begun to enjoy new popularity in ultra-nationalist circles. At the same time, more serious reevaluations of $\mathrm{CzF}$ by professional linguists have also appeared. In her $\mathrm{PhD}$ thesis, Renáta Németh (2007) - with reference especially to the work of Békés (1997) and Thomas Kuhn's (1962) famous model of scientific paradigm changes - claims that latter-day critics have failed to understand the philosophical background of CzF. I will come back to these re-evaluation attempts in the following chapters. Before that, however, a surprisingly similar attempt to apply the concept of 'root' in 19th-century Finnish etymology will be briefly presented.

\subsection{Finland: Otto Donner's forgotten Vergleichendes Wörterbuch}

Otto Donner (1835-1909), the first professor of Sanskrit and comparative Indo-European linguistics at the University of Helsinki, is now remembered mainly as a promoter of Finno-Ugric and "Altaic" studies. Before Indo-European studies, he had studied Finnish language and literature, and he maintained his interest in the Finnish language throughout his life.

In 1874, the first part of Donner's comparative dictionary of the Finno-Ugric languages (Vergleichendes Wörterbuch der FinnischUgrischen Sprachen) appeared, an attempt to apply the root theory of early Indo-European studies to the - then still sparsely documented Finno-Ugric languages. (The second and third parts came out in 1876 and 1888, but the work was left unfinished.) In the foreword of the dictionary, Donner regrets that he has not been able to access Kresznerics's Hungarian root dictionary, which would have been an important point of comparison for his work, "if Kresznerics really 
has presented roots in the sense of modern linguistics; whether this is the case I do not know". (Donner 1874: V, my translation.) Furthermore, Donner mentions the etymological word lists and dictionaries by the early Hungarian Finno-Ugrists Hunfalvy (1853) and Budenz (1873-1881), neither of which was accessible to him while writing his dictionary (Donner 1874: VII). In contrast, he makes no mention of $\mathrm{CzF}$, the last volume of which appeared in the same year, 1874.

Unlike Czuczor and Fogarasi, Donner was not creating his own speculative model of root analysis but applying contemporary models from Indo-European comparative linguistics. Accordingly, the preface in Donner's dictionary is very brief, merely three pages, and he does not really describe his method or even define such basic concepts as the 'root' (Wurzel). Practically the only technical detail he explicitly mentions is the existence of vowel alternations: contrary to the widespread assumption that the "root" in Uralic, or in Altaic in general, remains "rigid", Donner emphasizes that with all roots, Vokalsteigerung and "weakening of the root vowel" do appear, in a way essentially identical with Indo-European Gunierung and Schwächung.

Despite the different theoretical background, Donner thus ends up presenting examples of the Finno-Ugric vocabulary in a way which is, in essence, very similar to $\mathrm{CzF}$. Words from Finnish and related languages are grouped on the basis of their roots, which, in turn, may display internal vowel alternations or be extended with further (consonantal) elements. For instance, the root $\mathrm{kal}, \mathrm{kol}, \mathrm{kul}$, kel, kil denotes something 'smooth, shiny, pale, cold' and also comes with Steigerung forms kâl $(h \bar{a} l), k u o l, k u e l, k \bar{l} l$. To this belong Fi. kala Hung. hal 'fish' as well as Fi. kelo 'dried, withered pine tree', kaljama 'slippery, icy (road) surface', keli '(winter) road condition' (Donner: 'ice track'), kallo 'cranium' and kallio 'rock', kalvo and kelmu 'membrane', kalpea 'pale', kylmä 'cold', Est. kiilas 'bald', Fi. kuole- Hung. hal 'die', even Fi. kuu Hung. hold 'moon' and many others. (Donner 1874: 59-64.)

A further similarity appears in the treatment of loanwords. Although $\mathrm{CzF}$ does recognize the possibility of borrowing, the authors explicitly refrain from drawing etymological conclusions. They present comparisons also with words "from such languages which presumably (hypothetice) belong to other language families, something that certain linguists who cling to language classification systems deliberately avoid and even tell others to avoid" (CzF I: 21, my translation). In a similar way, Donner states that he will in his dictionary refer to formally and semantically similar Indo-European and other roots simply in order to point out the similarities, leaving the final etymological conclusions 
open for further research (Donner 1874: VI-VII). However, whether understood as loan etymologies or as possible cognates, from today's view many of Donner's Indo-European-Uralic word comparisons are "somewhat arbitrary and peculiar" (ziemlich willkürlich und eigenartig, Joki 1973: 35).

In the history of Finnish linguistics, Donner's dictionary is typically seen as an experiment which was "condemned to failure at the outset" (Korhonen 1986: 101). The attempt to apply Indo-European root theory and Ablaut to Finno-Ugric sealed the dictionary's fate and doomed it to oblivion (Stipa 1990: 322-323, Hovdhaugen et al. 2000: 178), as the new Neogrammarian paradigm introduced new requirements for exactness and precision of methods. (Actually, in connection with this process, Korhonen - similarly to Békés (1997) for Hungary has referred to Thomas Kuhn's model of paradigm change in science; Korhonen 1986: 122, 129.) The dictionary is not even mentioned in the article about Otto Donner in the Finnish National Biography (Väisänen 2001). Finnish linguists today know Donner's dictionary, if at all, as an historical curiosity. Calling it "one of the fundamental works of Finnish linguistics" (a finn nyelvészet egyik alapmüve), as Czakó (2013: 14) does, with reference to Pusztay $(2011)^{2}$, is, to put it mildly, modified truth.

\section{Expressive words and irregular word formation in modern Finnish etymological research}

The Neogrammarian paradigm, with its quasi-exact rules for the description of historical processes, maintained its influence in Finland practically until the 1960s (Hovdhaugen et al. 2000: 335-337, 509-510). For etymological research, this meant that the history of words could only be described in terms of strict rules of historical phonology, sound laws or analogy. Irregular consonant or vowel alternations or Gestaltbased, non-compositional word formation were accepted to some extent in the area of affective and expressive vocabulary. However, this was a difficult and dangerous object of study, and those few linguists who ventured into this area could jeopardize their academic career. A case in point was the dialectologist Ahti Rytkönen, whose "unorthodox"

2 Czakó as a layman is of course not competent to assess the importance of Donner's work. It is not clear where Pusztay has used the expression "one of the basic works"; in any case, I cannot find anything like that in Pusztay's 2011 book. 
doctoral dissertation was not allowed to public examination in the 1940s (Tainio 1995, Savolainen 1999, Hamunen 2016).

From the 1970s on, research of irregular word formation in Finnic gained new momentum (see also Anttila 1975). Sivula (1989) introduced a new term from botanics, rönsy 'shoot, stolon', to describe how irregular variants for affective words come into being. Nikkilä (1998) described the mechanisms of suffix change, i.e. metanalyses and irregular relations between stem variants such as Finnish hie(-)kka, hie(-) $t a$, and hie(-)su 'sand', monomorphemic stems secondarily reanalyzed as containing suffixes which can alternate. Jarva $(2001,2003)$ studied the intertwining of Russian loanwords with expressive word formation models, developing the idea of a word being "partly borrowed", while Mikone $(2001,2002)$ attempted to define and systematize the study of expressive words. One of the main motivations for the systematic study of expressive words was the editing of a new etymological dictionary, Suomen sanojen alkuperä (SSA) in the 1990s. Two of the authors of the dictionary, Ulla-Maija Kulonen (later: Forsberg, the editor-in-chief) and Eino Koponen, came to play a decisive role in the major etymological debate at the turn of the millennium.

The most dramatic part of the debate took place between Jorma Koivulehto, who in the last decades of the 20th century identified dozens of Indo-European loanwords in Finnic (partly even in other Uralic languages), and Eino Koponen, who proposed alternative "internal" etymologies for some of them. Koponen $(1997,1998)$ based his argumentation on the fact that expressive words, characterized by stem-internal vowel alternations (as in Finnish sihise- $\sim$ suhisesahise- $\sim$ sohise- $\sim$ sähise-, all onomatopoeic verbs denoting various kinds of hissing or rustling sounds), tend to 'fade' and lose their expressive character. This led him to postulate monosyllabic 'roots' with alternating vowels for many non-expressive words as well: words such as terä 'cutting edge', tarkka 'precise, sharp', törmä 'steep bank', turkki 'fur' etc. could all represent extensions of the originally expressive root ${ }^{\top} t r$ - ('something protruding or sharp'?). Koivulehto (2001: 61) sums up his sharp criticism by stating that Koponen's method leads to complete arbitrariness: its explanatory potential is infinite, as any word can be explained away as a faded expressive word. The same problem is also identified, although in a less belligerent wording, by Nikkilä (2001). Junttila $(2015: 142,169)$ summarizes the main problem: the expressive character of a word was misinterpreted as an etymological explanation in its own right. 
The SSA often explicitly refers to expressiveness or phonetical motivation and applies methods which bear a strong resemblance to Koponen's root model, although with conspicuously cautious wordings (cf. also Laakso 2002). For example, in the word entry silpoa 'shred, mutilate' it is stated (my translation): "In the background [!], there is a stem element sil-, connected with 'cutting', to which the derivative sileä ['smooth'] may also belong [...] It might be a very old descriptive element, cf. salia ['split (wood)'], salvaa ['castrate' (v.)], salvoa ['join the logs of a building at the corner'], and säle ['splinter']."

The ideas of abstract phonesthemic schemas as a means of expressive word formation have been developed further by Forsberg (2010). She points out that even ancient etyma may contain obvious sound symbolism, as in the case of the three Finno-Ugric "mouth words" with an initial *'n and a stem-internal $l$ : *neli- (Hungarian nyel 'swallow' (v.) North Saami njiellat $\sim$ Finnish niellä etc.), *nali- (Hung. nyal 'lick' North Saami njuollat $\sim$ Finnish nuolla etc.), and *nälmä/*nälwä (Hung. nyelv 'tongue' North Saami njálbmi 'mouth'). ${ }^{3}$ She also claims that phonesthemic schemas or "roots" may be as ancient as nonexpressive words, the only distinction being "that we cannot reconstruct words with a special meaning, only a root" (op. cit. 13). For instance, the Finno-Ugric words for 'butterfly' such as Estonian liblikas, Mansi löäp $\chi$ and Hungarian lepke are not etymological cognates in the traditional sense, but together with many other expressive words they may reflect the possibly ancient phonestheme \#lipi, connected with 'something fluttering or flapping' (op. cit. 13-14).

Before phonesthemic schemas or "roots" can be used as tools in historical-comparative linguistics, more systematic research is needed. Sadly enough, sound symbolism, even if some of its features may be universal - as was claimed in a recent study (Blasi et al. 2016) - is partly language-specific and subject to change. Certain expressive features may be old, stable or reconstructible. For instance, Forsberg (Kulonen 2006, Forsberg 2010: 7-8) notes that in reconstructed FinnoUgric vocabulary the combination of word-internal nasal and affricate (-nčc-, $\left.-n^{\prime} c^{-}\right)$appears in many words denoting small animals or insects (fly, flea, ant, lizard); this looks like a reconstructible sound-symbolic pattern. However, as Aikio (2001) has pointed out, even fairly closely

3 The reconstructed proto-forms were not given in Forsberg's paper. Note that Janhunen (1992) has explained the Hung. nyelv with its cognates as an ancient deverbal noun derived from the verb 'swallow' (*näxli-mä), which would reduce the number of original ancient sound-symbolic *n'Vl-stems to two. 
related language groups such as Finnic and Saami may have completely different attraction centres for sound symbolism. Moreover, it is well known that expressive word formation often makes use of the expressive force of new phonemes or phonotactic innovations (see e.g. Ravila 1952, Klaas 1995).

Furthermore, there are no systematic or universal criteria for expressiveness. It is well known that expressive words may lose their expressive character, so that their original sound-symbolic motivation is no more obvious. This, in turn, may lead to circular reasoning: the word is in a root relationship with another word because it was originally expressive, and it was originally expressive because we can construct an abstract root behind it and its putative relatives.

Although the debate around Koponen's root model seems to have died out and Forsberg's phonestheme reconstructions have not aroused any particular opposition, it is still too early to claim that the root as a concept has established itself in Finnish etymological research. Moreover, there seems to be no pressing need among Finnish linguists or laymen to use and popularize the concept of root or to connect it with ideological or political questions - unlike what is happening in Hungary.

\section{The root and the politicization of linguistic discourse in Hungary}

In Hungary today, nationalistically motivated pseudolinguistic ideas, often explicitly opposing the idea of Finno-Ugric relatedness, enjoy an increasing popularity. The proponents of these ideas sometimes celebrate $\mathrm{CzF}$, using it as evidence of the unique structure of Hungarian. Until the last few years, "alternative" ideas harshly criticized by experts of Finno-Ugric linguistics (Rédei 2003, Honti (ed.) 2010) have mostly been voiced by non-linguist dilettantes, sometimes by maverick linguists ${ }^{4}$ such as Angela Marcantonio (2002, for criticism see e.g. Aikio 2003, Bakró-Nagy 2005, de Smit 2003, Laakso 2004, Saarikivi 2004) or László Marácz (see also Marácz [n.d.], Marácz 2002). Now, however, it seems that a new form of "respectable root linguistics" is emerging.

A case in point are the parallel Czuczor-Fogarasi conferences. In 2012 , to celebrate the 150th anniversary of the first volume of $\mathrm{CzF}$, a

4 For the concept of "maverick linguist”, cf. Newbrook (2013). 
conference was organized by László Marácz, featuring mostly laymen or maverick linguists (Marácz et al. 2012). In the same year, however, another conference - already the second one of its kind - was hosted by the Hungarian Academy of Arts (Magyar Müvészeti Akadémia, MMA), ${ }^{5}$ and many of its participants were academic linguists, even FinnoUgrists.

In the foreword to the publication of the latter conference (Horvatth [ed.] 2013), its editor clearly states that the etymological equations in $\mathrm{CzF}$ "must be treated with strict criticism, and their data must be controlled in accordance with today's scientific criteria" (Horváth 2013a: 9, my translation). At the same time, however, most if not all authors of the volume seem to agree that the root model is a valid way of describing internal relationships in the lexicon of Hungarian.

Referring to CzF's idea that words by way of their roots have both "descendent" (suffixing or suffix-changing) and "collateral" (oldalági, i.e. root-alternating) relations, Horváth is convinced that "acknowledging the double etymological connections of the roots was an important thought in its time [...], and Hungarian etymological research would have made better progress if it had pursued this initiative and fulfilled its potential" (Horváth 2013b: 130, my translation). In the same volume, Lóránt Bencze (2013: 28-31) insinuates that the traditional etymological explanation of Hung. terem 'room, hall' as an East Slavic loanword was possibly influenced by political pressure from Russia (!) under Socialism. In Bencze's view, we should, instead of this isolate etymology, ${ }^{6}$ rather focus on language-internal association networks which connect terem with tér 'space, area, place', tér [v.] 'return', terem 'grow', and their numerous derivatives. And in this sense, we should even consider accepting consonant or vowel alternations: tár 'storeroom, magazine', tág 'wide' or tag 'member' ("extension in space", as Bence points out), tele 'full' or töm 'fill', among many others, can all be semantically related to the same root... Géza Balázs (2013: 57-58), in turn, praises $\mathrm{CzF}$ for its unprejudiced search for specifically Hungarian characteristics in language structure and the internal motivation of words. Claiming (without further elaboration) that the root theory is actually an earlier version of modern network theories, he states that

5 The MMA was originally a club of conservative-nationalist artists. The current government has developed it into a state institution and placed it in charge of various cultural policies and their funding.

6 While claiming that terem is an isolate (szócsalád nélküli) word in East Slavic, Bencze fails to mention the traditional Greek loan etymology given in Vasmer (1955). 
some Finno-Ugric languages and certainly Hungarian show a "partially functioning root system" (op. cit. 51).

To sum up, in this new framework of revised root theories, tenets generally acknowledged by the linguistic community worldwide (such as the historical relatedness of the Finno-Ugric languages) are no more openly denied. Political conspiracy theories remain between the lines, but a more subtle emphasis is placed on the uniqueness of the Hungarian language and the philosophical backgrounds of $\mathrm{CzF}$ and other alternative models, thus relativizing criticism and fostering less belligerent forms of linguistic exceptionalism. It is difficult not to see this as a reflection of nationalist ideologies.

\section{Conclusion: Why, and why not?}

The methods by which the history of Finno-Ugric, Indo-European, and other language families have been charted are based on the arbitrariness of signs which make the basic building blocks of language subject to language-internal rules only. Whether the word for 'tree' begins with a labial consonant or whether there are rounded front vowels has nothing to do with the eco-socio-political or cultural contexts in which the language is spoken. Thanks to this, linguists have been able to construct and reconstruct sound systems and the changes of sounds and meanings. Despite all criticism to the notorious Neogrammarian "principle of exceptionless sound laws", the regularity of sound change is a very well working scientific hypothesis proven in countless studies during more than a hundred years (cf. Ringe and Eska 2013: 3-4), and without the uniformitarian principle, that is, the idea that all languages living and dead obey the same general laws, linguistic reconstruction and comparative-historical linguistics would have been impossible.

There are, of course, more things in heaven, earth, and the history of our languages than are dreamt of in our historical linguistics. Words can and do change also on the basis of grammatically, semantically or syntagmatically motivated association networks ("analogies"), and phonesthetic sound symbolism is a real, partly perhaps even universal factor behind certain developments. These associations and connections, existing outside and beyond the regularities of phonology and morphology, make the expressive lexicon as well as language contact phenomena so tricky to investigate. They give rise to the aforementioned reanalyses and irregular developments in derivation or in the adaptation of loanwords: nativization (cf. Aikio 2007, Ringe and Eska 
2013: 61-62), descriptivization (cf. Jarva 2003), or "docking" or the identification of foreign elements with inherited ones (Laakso 2001).

However, the value of these explanations is precisely in their individual applicability. Their empirical adequacy is based on more general laws of psychology, psycholinguistics and human cognition - association is a powerful and real mechanism, as already the Neogrammarians knew. For this reason, they are too general to explain the functioning and development of a very specific system like language: no language we know of functions solely on the basis of perceived similarities, associations, or phonesthetic symbolism.

A Hungarian speaker may well, as Bencze (2013: 31-32) states, associate the internationalism szerviz 'service (station)' with Hungarian words such as szerel 'install, maintain (a machine)' or szerszám 'tool'. In this sense, we could speak of the integration of szerviz into the system of Hungarian or even its "partial etymology". But postulating a Hungarian root szer-does not in itself explain anything nor add anything to our understanding of these associations or their effects. It will merely provide a Procrustean conceptual framework which - paradoxically enough, considering the nationalist agenda of the author - slavishly and prescientifically copies a foreign model.

Guided by their speculative preconceptions, Czuczor and Fogarasi as well as Donner, despite their different theoretical and philosophical backgrounds, ended up at the same dead end. Recent developments in the study of Finnic expressive vocabulary, in contrast, illustrate both the dangers and the new opportunities in exploring the supra-morphological mechanisms of morphotactics and word formation.

\author{
Address: \\ Johanna Laakso \\ Universität Wien \\ Institut für Europäische und Vergleichende Sprach- und \\ Literaturwissenschaft (EVSL) \\ Abteilung Finno-Ugristik \\ Universitätscampus Spitalgasse 2-4 Hof 7 \\ A-1090 Wien, Austria \\ E-mail: johanna.laakso@univie.ac.at
}




\section{References}

Aikio, Ante (2001) “Miten kuvaannollisuus selittää sanoja?” Tieteessä tapahtuu 2001/4, $61-63$.

Aikio, Ante (2003) [Review of Marcantonio 2002.] Word 3/2003, 401-412.

Aikio, Ante (2007) "Etymological nativization of loanwords: a case study of Saami and Finnish.” In Ida Toivonen and Diane Nelson, eds. Saami Linguistics, 17-52. Amsterdam: John Benjamins.

Anttila, Raimo (1975) “Affective vocabulary in Finnish: An(other) invitation." UralAltaische Jahrbücher 47, 10-19.

Bakró-Nagy, Marianne (2005) "The responsibility of literati." [Review of Marcantonio 2002.] Lingua 115, 1053-1062.

Balázs, Géza (2013) “A nyelvtörténet kiterjesztése.” In Katalin Horváth, ed. II. Czuczor-Fogarasi-konferencia: "Ha szabad a magyart a magyarból magyarázni", 47-59. (A Magyar Múvészeti Akadémia Konferenciafüzetei 2.) Budapest: Magyar Mủvészeti Akadémia.

Békés, Vera (1997) A hiányzó paradigma. Debrecen: Latin Betük.

Bencze, Lóránt (2013) “Omnes leones leonizare.” In Katalin Horváth, ed. II. CzuczorFogarasi-konferencia: "Ha szabad a magyart a magyarból magyarázni”, 23-46. (A Magyar Müvészeti Akadémia Konferenciafüzetei 2.) Budapest: Magyar Müvészeti Akadémia.

Blasi, Damián, Søren Wichmann, Harald Hammarström, Peter F. Stadler, and Morten H. Christiansen (2016) "Sound-meaning association biases evidenced across thousands of languages." PNAS 113, 39, 10818-10823. DOI: 10.1073/pnas.1605782113

Budenz, József (1873-1881) Magyar-Ugor összehasonlitó szótár. Budapest: Magyar Tudományos Akadémia.

Czakó, Gábor (2013) “Az elsüllyesztett magyar nyelvtan főbb vonásairól: A magyar nyelv alaptörvénye a gyökmüködés." In Katalin Horváth, ed. II. Czuczor-Fogarasikonferencia: "Ha szabad a magyart a magyarból magyarázni", 11-22. (A Magyar Müvészeti Akadémia Konferenciafüzetei 2.) Budapest: Magyar Mủvészeti Akadémia.

Czuczor, Gergely and János Fogarasi (1862-1874) A magyar nyelv szótára. Pest.

de Smit, Merlijn (2003) [Review of Marcantonio 2002.] Linguistica Uralica 39, 57-67.

Donner, Otto $(1874,1876,1888)$ Vertaileva sanakirja Suomalais-Ugrilaisten kielten alalla $=$ Vergleichendes Wörterbuch der Finnisch-Ugrischen Sprachen I-III. Helsinki.

Forsberg, Ulla-Maija (2010) "Expressive vocabulary in the early phases of FinnoUgrian.” In Congressus XI Internationalis Fenno-Ugristarum, Piliscsaba 2010. Pars I: Orationes plenariae, 5-20. Piliscsaba: Reguly-Társaśag.

Fortson IV., Benjamin W. (2004) Indo-European language and culture. Oxford/Malden/ Victoria: Blackwell.

Hamunen, Markus (2016) "Puh pah pelistä pois. Ahti Rytkösen tm-tutkimuksen taustoja." Virittäjä 120, 304-359. 
Honti, László ed. (2010) A nyelvrokonságról. Az török, sumer és egyéb áfium ellen való orvosság. Budapest: Tinta Könyvkiadó.

Horváth, Katalin ed. (2013) II. Czuczor-Fogarasi-konferencia. "Ha szabad a magyart a magyarból magyarázni.” (A Magyar Művészeti Akadémia Konferenciafüzetei 2.) Budapest: Magyar Mủvészeti Akadémia.

Horváth, Katalin (2013a) "Előszó". In Katalin Horváth, ed. II. Czuczor-Fogarasikonferencia. "Ha szabad a magyart a magyarból magyarázni.", 7-10. (A Magyar Mủvészeti Akadémia Konferenciafüzetei 2.) Budapest: Magyar Müvészeti Akadémia.

Horváth, Katalin (2013b) "Etimológiánk és a Nagyszótár szófejtő gyakorlata." In Katalin Horváth, Katalin ed. (2013) II. Czuczor-Fogarasi-konferencia. "Ha szabad a magyart a magyarból magyarázni.”, 119-137. (A Magyar Mủvészeti Akadémia Konferenciafüzetei 2.) Budapest: Magyar Müvészeti Akadémia.

Hovdhaugen, Even, Fred Karlsson, Carol Henriksen, and Bengt Sigurd (2000) The history of linguistics in the nordic countries. Helsinki: Societas Scientiarum Fennica.

Hunfalvy, Pál (1853) A magyar és finn szók összehasonlitása. Budapest.

Janhunen, Juha (1992) “Petrified verbal nouns in Early Uralic.” In Pál Deréky, Marianne Bakró-Nagy, Timothy Riese, and Péter Hajdú eds. Festschrift für Károly Rédei zum 60. Geburtstag, 239-244. (Studia Uralica 6; Urálisztikai Tanulmányok 3.) Wien/Budapest: Harrassowitz.

Jarva, Vesa (2001) "Some expressive and borrowed elements in the lexicon of Finnish dialects.” In F. K. Erhard Voeltz and Christa Kilian-Hatz, eds. Ideophones, 111-119. (Typological studies in language 44.) Amsterdam/Philadelphia: John Benjamins.

Jarva, Vesa (2003) Venäläisperäisyys ja ekspressiivisyys suomen murteiden sanastossa. (Jyväskylä Studies in Humanities 5.) Jyväskylä: University of Jyväskylä.

Joki, Aulis J. (1973) Uralier und Indogermanen: die älteren Berührungen zwischen den uralischen und indogermanischen Sprachen. (Mémoires de la Société FinnoOugrienne 151.) Helsinki: Finno-Ugrian Society.

Junttila, Santeri (2015) Tiedon kumuloituminen ja trendit lainasanatutkimuksessa: kantasuomen balttilaislainojen tutkimushistoria. Helsinki: Helsingin yliopisto.

Klaas, Birute (1995) "Über den Ursprung der anlautenden Konsonantenverbindungen der estnischen und finnischen Sprachen.” In Seppo Suhonen, ed., Itämerensuomalainen kulttuurialue, 108-131. (Castrenianumin toimitteita 49.) Helsinki: Suomalais-Ugrilainen Seura.

Koivulehto, Jorma (2001) "Etymologie und Lehnwortforschung: ein Überblick um 2000.” Finnisch-Ugrische Forschungen 56, 42-78.

Koponen, Eino (1997) "Puhdasta puhetta?” Virittäjä 101, 440-442.

Koponen, Eino (1998) Eteläviron murteen sanaston alkuperä. Itämerensuomalaista etymologiaa. (Mémoires de la Société Finno-Ougrienne 230.) Helsinki: SuomalaisUgrilainen Seura.

Korhonen, Mikko (1986) Finno-Ugrian Language Studies in Finland 1828-1918. Helsinki: Societas Scientiarum Fennica.

Kresznerics, Ferenc (1831-1832) Magyar szótár gyökérrenddel és deákkozattal. Buda. (Facsimile version: Budapest: Tinta Kiadó, 2010.)

Kuhn, Thomas (1962) The structure of scientific revolutions. Chicago: University of Chicago Press. 
Kulonen, Ulla-Maija (2006) “Eläimet ja affekti: etymologisia huomioita.” Virittäjä 110, $322-335$.

Laakso, Johanna (2001) "Reflections on the verb suffix -om in Russenorsk and some preliminary remarks on “docking” in language contact.” In Sándor Maticsák, Gábor Zaicz, and Tuomo Lahdelma, eds. Ünnepi könyv Keresztes László tiszteletére, 315-324. (Folia Uralica Debreceniensia 8.) Debrecen - Jyväskylä.

Laakso, Johanna (2002) "Das letzte Wort ist noch nicht gesprochen." [Review of SSA, Vol. 3.] Finnisch-Ugrische Forschungen 57, 363-370.

Laakso, Johanna (2004) "Sprachwissenschaftliche Spiegelfechterei." [Rev. of Marcantonio 2002.] Finnisch-Ugrische Forschungen 58, 296-307.

Laakso, Johanna (2010) "On the difficulty of popularizing Finno-Ugric studies." In Valentin Gusev and Anna Widmer, eds. Gedenkschrift Eugen Helimski, 375-388. (Finnisch-Ugrische Mitteilungen 32/33.) Hamburg: Buske.

Marácz László (s.a.) The untenability of the Finno-Ugric theory from a linguistic point of view. Available online at $<\mathrm{http}$ ://www.magtudin.org/Maracz\%20L.\%20Untenability\%20of\%20Finno-Ugric\%20Theory.htm. Accessed on 21.06.2014.

Marácz, László (2002) "Nyelvi és képi gyökök - a magyar kultúra megtartói.” Ökotáj 29-30/2002. Available online at <http://www.okotaj.hu/szamok/29-30/betu2.htm>. Accessed 21.06.2014.

Marácz, László (2009) Hungarian revival: Political reflection on Central Europe. The Hague: Mikes International.

Marácz, László, Zsolt Molnár, and Cecília Molnárné Czeglédi, Cecília (2012) "Report on the International Czuczor-Fogarasi Conference, Budaörs, October 6-7, 2012.” Journal of Eurasian Studies IV: 4, 189-191. Available online at $<$ http://www.federatio.org/joes/EurasianStudies_0412.pdf > . Accessed 21 June 2014.

Marcantonio, Angela (2002) The Uralic language family: Facts, myths, and statistics. (Publications of the Philological Society 35.) Oxford/Boston: Blackwell.

Mikone, Eve (2001) "Ideophones in the Balto-Finnic languages." In F. K. Erhard Voeltz and Christa Kilian-Hatz, eds. Ideophones, 223-234. (Typological Studies in Language 44.) Amsterdam/Philadelphia: John Benjamins.

Mikone, Eve (2002) Deskriptiiviset sanat: määritelmät, muoto ja merkitys. Helsinki: Suomalaisen Kirjallisuuden Seura.

Morpurgo Davies, Anna (1998) History of linguistics IV: Nineteenth-century linguistics. London: Longman.

Németh, Renáta (2007) A XIX. századi nyelvbölcselet és A magyar nyelv szótárának etimológiai elvei. Unpublished $\mathrm{PhD}$ thesis, ELTE University Budapest. Available online at $<$ http://doktori.btk.elte.hu/lingv/nemethrenata/disszert.pdf $>$. Accessed 14 June 2014.

Newbrook, Mark (2013) Strange linguistics: A skeptical linguist looks at non-mainstream ideas about language. München: LINCOM Europa.

Nikkilä, Osmo (1998) “nop-ea $\rightarrow$ nop-sa, sel-keä $\rightarrow$ sel-vä: Suffiksinvaihto ja suomen sanojen etymologiointi." In Urho Määttä and Klaus Laalo, eds. Kirjoituksia muotoja merkitysopista, 77-101. (Folia Fennistica \& Linguistica 21.) Tampere: University of Tampere. 
Nikkilä, Osmo (2001) [Review of Koponen 1998.] Linguistica Uralica 37, 57-65.

Pusztay, János (2011) Gyökereink. [S. 1.]: Nap Kiadó.

Ravila, Paavo (1952) "Onomatopoieettisten ja deskriptiivisten sanojen asema kielen äännesysteemissä.” Virittäjä 56, 262-273.

Rédei, Károly (2003) Östörténetünk kérdései. 2nd ed. Budapest: Balassi Kiadó.

Ringe, Don and Joseph F. Eska (2013) Historical linguistics. Towards a twenty-first century reintegration. Cambridge University Press.

Saarikivi, Janne (2004) [Review of Marcantonio 2002.] Journal of Linguistics 40/1, 187-191.

Savolainen, Marjo (1999) Ahti Rytkönen ekspressiivisanatutkijana: oppihistoriallinen katsaus ekspressiivisanatutkimukseen. M. A. thesis, University of Jyväskylä. Available online at <http://urn.fi/URN:NBN:fi:jyu-1999829629>. Accessed 18 June 2014.

Sivula, Jaakko (1989) Lintu soidessa sokea: suomen murteiden kiimatermistö. Helsinki: Suomalaisen Kirjallisuuden Seura.

$S S A=$ Itkonen, Erkki (editor-in-chief, Vol. I) and Ulla-Maija Kulonen (editor-in-chief, Vol. I-III), eds. (1992, 1995, 2000) Suomen sanojen alkuperä. Etymologinen sanakirja I-III. Helsinki: Suomalaisen Kirjallisuuden Seura.

Stipa, Günter Johannes (1990) Finnisch-ugrische Sprachforschung von der Renaissance bis zum Neupositivismus. (Mémoires de la Société Finno-Ougrienne 206.) Helsinki: Suomalais-Ugrilainen Seura.

Tainio, Liisa (1995) “Ahti Rytkönen kielentutkimuksen työmaalla.” Virittäjä 99, $437-445$.

Väisänen, Maija (2001) “Donner, Otto (1835-1909)”. In Kansallisbiografia-verkkojulkaisu. Available online at <http://www.kansallisbiografia.fi/kb/artikkeli/3179/>. Accessed 14 June 2014.

Vasmer, Max (1955) Russisches etymologisches Wörterbuch. Heidelberg: Winter.

\begin{abstract}
Kokkuvõte. Johanna Laakso: Tagasi juurte juurde? Arutlus "juure" mõiste üle soome-ugri keeleteaduses. Soome-ugri keeleteaduses on tavaks vaadelda sõnu tüvede ja liidetena, mitte abstraktsete ühesilbiliste juurtena indoeuroopa keeleteaduse mõistes. Ajalooliselt kahesilbiliste tüvede kõrval on püütud tarvitusele võtta ka juure mõiste, et seletada ekspressiivsele sõnavarale omaseid vähem reeglipäraseid sõnadevahelisi seoseid ning sõnamoodustusmehhanisme. Artiklis võetakse kriitiliselt vaatluse alla mõned neist katsetest nende ajaloolises ja ideoloogilises kontekstis.
\end{abstract}

Märksõnad: soome-ugri keeled, ungari keel, soome keel, sõnastruktuur, etümoloogia, juur, keeleteaduse ajalugu, ekspressiivsed sõnad 